ROCZNIKI HUMANISTYCZNE

Tom LXVIII, zeszyt 7 - 2020

DOI: http://dx.doi.org/10.18290/rh20687-4

MONIKA SIDOR

\title{
DRÓŻKA ALEKSANDRA SOŁŻENICYNA \\ W KONTEKŚCIE LITERATURY NAIWNEJ \\ I FOLKLORU ŁAGROWEGO
}

Poemat Dróżka (Дороженька) należy do tej części dorobku Aleksandra Sołżenicyna, która, mimo sławy twórcy, właściwie pozostaje niezbadana. Przyczyn tej sytuacji jest wiele, ale bodaj najistotniejszą podał sam autor, przyznając, że poziom artystyczny jego twórczości poetyckiej, podobnie jak dramatycznej, nigdy go nie satysfakcjonował (Солженицын, „Предисловие” 148). Те̨ ocenę jednym głosem podtrzymują literaturoznawcy zajmujący się spuścizną pisarza, twierdząc, że najlepiej talent rosyjskiego noblisty przejawił się $\mathrm{w}$ prozie $\mathrm{i}$ inne formy wypowiedzi nie utrzymują równie wysokiego poziomu jak powieści, opowiadania czy publicystyka.

Nie znaczy to jednak, że Sołżenicynowska twórczość poetycka powinna być nieczytana i niebadana. W moim przekonaniu takie pominięcie nie pozwala zobaczyć w pełni charakteru pisarskiego autora i pozbawia wszystkie badania nad jego twórczością pewnego ważnego elementu, swoistej artystycznej prehistorii, wglądu w okoliczności ukształtowania się indywidualnego stylu. Chodzi bowiem o utwory wyprzedzające głośny debiut literacki Jeden dzień Iwana Denisowicza (Один день Ивана Денисовича, 1962), a tematycznie jemu bliskie. Proponuję badania nad tymi pomijanymi milczeniem utworami nie po to, aby udowadniać ich wartość literacką, lecz aby ustalić ich cechy szczególne i ich miejsce w procesie odnajdowania przez

Dr hab. MONIKA SIDOR, prof. KUL - Katolicki Uniwersytet Lubelski Jana Pawła II, Wydział Nauk Humanistycznych, Instytut Literaturoznawstwa, Katedra Literatury Rosyjskiej, Ukraińskiej i Białoruskiej; adres do korespondencji: Al. Racławickie 14, 20-950 Lublin; e-mail: monyd@kul.pl; ORCID: https://orcid.org/0000-0002-8290-8682.

Dr. habil. MoniKa SIDOR, prof. at KUL - John Paul II Catholic University of Lublin, Faculty of Humanities, Institute of Literary Studies, Department of Russian, Ukrainian and Belarusian Literature; address for correspondence: Al. Racławickie 14, 20-950 Lublin; e-mail: monyd@kul.pl; ORCID: https://orcid.org/0000-0002-8290-8682. 
Sołżenicyna swojego własnego głosu. Wychwycenie rysów dystynktywnych tych tekstów pozwoli bowiem ukazać pewien etap krystalizacji metody artystycznej autora. Tę myśl werbalizują zresztą niektórzy znawcy twórczości pisarza, ubolewając jednocześnie, że takie badania nie są prowadzone (Николсон 256). Odczuwając potrzebę uzupełnienia tej badawczej luki, zajmę się tu przede wszystkim poematem Dróżka, który powstawał w latach 1948-1952, ale zwrócę także uwagę na wybrane przykłady poezji, które kontynuują jego tematykę lub odnoszą się do procesu jego tworzenia. Sołżenicyn pisał wiersze między 1946 a 1953 r., a więc tuż po aresztowaniu i przez cały czas spędzony w więzieniach i łagrach, lecz przez wiele lat pozostawił je bez publikacji. Niewielkie fragmenty poematu Dróżka zostały wydrukowane w Paryżu w 1974 r. jako oddzielny utwór pod nazwą Прусские ночи, potem w prasie emigracyjnej pojawiały się inne wyimki z tego tekstu, zwykle opatrzone odrębnymi tytułami (Егоров 148), a pierwsze wspólne wydanie poezji więzienno-łagrowej Sołżenicyna nastąpiło w 1999 r. w paryskim zbiorze Протеревщи глаза.

Proponuję wstępną próbę odtworzenia wyznaczników estetycznych wczesnej twórczości Sołżenicyna, określenia artystycznego i życiowego tła powstania utworów poetyckich oraz ich roli i miejsca w procesie rozwoju twórczego autora. Dlatego dużą część rozważań wypadnie poświęcić kwestiom okołoliterackim, objaśnieniu kluczowych pojęć i przemianom ich zakresu znaczeniowego. Badania takie nie są nakierowane na udowodnienie talentu autora Archipelagu GUŁag (Архипелаг ГУЛаг, 1973), do czego dość często sprowadzają się podobne analizy dokonywane przez pokaźną już grupę sołżenicynologów. Chodzi raczej o wykazanie znaczenia takich kontekstów, które są przez ową grupę zazwyczaj zupełnie pomijane. Stawiam bowiem tezę, że utwory poetyckie pisane przez Sołżenicyna w okresie więzienno-łagrowym bliskie są folklorowi łagrowemu i literaturze naiwnej, a badanie ich w takim kluczu nie umniejsza wartości późniejszych dzieł z nurtu obozowego, lecz dostarcza ważnych informacji na temat ewolucji artystycznej autora. Przesłanki do postawienia powyższej tezy mają charakter historyczny i artystyczno-światopoglądowy, a uwzględniają okoliczności powstania utworów oraz ich cechy immanentne, rozpoznawalne w warstwie treści czy budowy. Niektóre z nich wydają się oczywiste, inne zaś uwidaczniają się przy bliższym oglądzie zagadnień związanych z folklorem łagrowym i literaturą naiwną. Ich udowodnienie jest kwestią szczegółowych analiz, które z konieczności zostaną tu okrojone jedynie do pewnych niezbędnych przykładów i będą wymagały dalszych badań. 
Zacznę od przesłanki pierwszej, oczywistej, która dotyczy warunków procesu twórczego. Już sam fakt powstawania poezji Sołżenicyna w więzieniach i obozach sprawia, że dla dzisiejszych folklorystów jest ona przykładem folkloru łagrowego. Warto jednak przyjrzeć się bliżej temu pojęciu i jego antecedencjom. Jego użycie implikuje określone rozumienie folkloru w ogóle, z kolei wieloznaczność towarzysząca temu ostatniemu od samych początków jego istnienia w obiegu naukowym wymaga doprecyzowania (Waliński 4-11). W miarę rozwoju folklorystyki formułowano różnorodne propozycje określenia jej przedmiotu, oscylujące od skrajnego rozszerzenia, kiedy za folklor przyjmowane były niemal wszystkie przejawy kultury materialnej i duchowej danej grupy etnicznej, do maksymalnego zawężenia, kiedy nazywano nim jedynie ustną twórczość ludową (Burszta 126). Violetta Wróblewska konstatuje więc dziś ,zamęt interpretacyjny” wynikający z rozpowszechnienia terminu, gdyż już w latach 70 . odnotowano jego nowe znaczenia: publicystyczne i potoczne, które z biegiem lat znacznie się rozszerzyły (Wróblewska 10) .

W obecnych badaniach folklor jest traktowany dość szeroko, w sensie najbliższym definicji Piotra Kowalskiego, jako „zbiór zachowań-tekstów, które współtworzą społeczną rzeczywistość” (Kowalski 131).

Są one aktywnym, akceptowanym repertuarem grupy społecznej, stanowią wspólne, „oczywiste” dobro przekazywane w bezpośrednich kontaktach. Przysługuje im znamię „nieoficjalności”, co odróżnia je funkcjonalnie i komunikacyjnie od treści i komunikatów w instytucjonalnych (...) kanałach przekazu.

(Kowalski 131)

Nie chodzi tu więc o „rzeczy ludowe” (Sobczyk 418) ani o kulturę wsi, gdyż termin ten obejmuje także „myśli i działania (...) populacji miejskiej (czyli ludu w społeczeństwach zdominowanych przez pismo)" (Goody 119). Jednocześnie wykorzystane tu rozumienie folkloru, uznając jego synkretyzm (Waliński 9; Sulima 7), nie będzie obejmowało wielu zjawisk dziś określanych tym mianem. Nie będą mnie interesowały, dostrzeżone przez Wróblewską, pozanaukowe zastosowania terminu „folklor” dla „oznaczenia zespołu słów i zachowań negatywnych, niekulturalnych, odstających znacznie od standardów obyczajowych, zwykle odnoszonych do ludzi nieokrzesanych, nieobytych" (Wróblewska 10).

Badaczka zwraca uwagę na wielokierunkową ewolucję tego pojęcia w dobie Internetu, w związku z którą folklorem są nazywane różnego typu zjawiska tworzone „na pograniczu kultury miejskiej oraz wiejskiej, edukowanej 
i amatorskiej”, takie jak „wytwory internetowe” czy przykłady „sztuki ulicy” (Wróblewska 13-14).

Granice chronologiczne wyznaczone przez badane tu utwory Sołżenicyna w naturalny sposób wykluczają takie najnowsze przejawy folkloru, związane z rozwojem współczesnych form komunikacji społecznej. Należy przy tym uznać zasadność socjologicznych kryteriów badanego zjawiska, na których podstawie Roch Sulima stwierdza, że „możemy mówić o folklorze robotniczym, o folklorze uczniowskim, studenckim, żołnierskim, o folklorze turystów, kibiców sportowych itp." (Sulima 6). Różnice między wymienionymi typami wynikają ze specyfiki danego środowiska, która wpływa na dobór najpopularniejszych tematów i wykorzystaną leksykę.

Wypada jednak zaznaczyć, że pojęcie „folklor łagrowy” ma również różne odcienie znaczeniowe. Niewątpliwie może być ono rozumiane jako po prostu twórczość więzienna i tak właśnie funkcjonuje w wielu badaniach. Ale można ją także przedstawić jako część folkloru przestępczego, w którym rozróżnienie „więzienny” czy „tworzony na wolności” nie ma mocy dystynktywnej. Zainteresowanie tym zjawiskiem badaczka rosyjska Jekaterina Jefimowa przedstawia jako część legitymujących się bardzo długim rodowodem, bo sięgającym wieku XV, szerokich badań nad środowiskiem przestępczym i fenomenem subkultury kryminalnej (Ефимова). Na obrzeżach tego nurtu znalazły się na przykład eksploracje liryki tworzonej przez więźniów, której znaczna część już od lat 20. XX wieku była drukowana na łamach periodyków przeznaczonych dla osadzonych. Wraz z rozwojem systemu penitencjarnego w ZSRR twórczość skazanych przybrała bardziej zróżnicowane formy, a zarazem jej oficjalne badania w Związku Radzieckim zostały uznane za ideologicznie podejrzane. Dużą część osiedleńców „małej zony” stanowili przecież więźniowie polityczni, których poglądy traktowano jako społecznie szkodliwe. Kultura tworzona w miejscach odosobnienia stała się więc tematem tabu dla badaczy, chociaż rozprzestrzeniała się własnymi kanałami i była znana nie tylko w środowisku przestępczym, lecz i poza nim (Терц 112-113). Tak zwane „błatne” pieśni znalazły się przecież w repertuarze wielu rosyjskich bardów już w latach $60 . \mathrm{XX}$ wieku.

Zwolennikiem pojęcia „folkor łagrowy” był sam Aleksander Sołżenicyn, za którego sprawą termin ten zyskał szeroki rozgłos. W Archipelagu GUŁag, w rozdziale Зэки как нация pisarz wyraził bowiem opinię, że w „zonie” żyje właściwie osobna społeczność, jakby odrębne plemię, które rządzi się własnymi prawami i posługuje się innym językiem niż reszta mieszkańców 
ZSRR. Sołżenicyn podkreślał u łagierników cechy, których nie wahał się nazwać specyficznym charakterem narodowym:

Именно ясно выраженный народный характер сразу замечает исследователь у зэков. У них есть и свой фольклор, и свои образы героев. Наконец, тесно объединяет их еще один уголок культуры, который уже неразрывно сливается с языком, и который мы лишь приблизительно можем описать бледным термином матерщина (от латинского mater). (485-486)

Pisarz poświęca cały rozdział swojej „encyklopedii łagrowej” na sarkastyczne badanie etnograficzne, gdzie za pomocą analizy poszczególnych elementów owego charakteru narodowego odrębność narodowa mieszkańców „małej zony” zostaje ostatecznie udowodniona. Autor, przynależąc do tego samego plemienia i doceniając trafność więziennej leksyki, uwypukla sens więziennych opowieści oraz sedno skazańczego humoru, lecz artystycznie pozostaje admiratorem kultury wysokiej. Wskazuje on jednocześnie na ciekawe zjawisko przenikania folkloru obozowego do środowiska „wielkiej zony" oraz akcentuje faktyczną bliskość aparatu państwowego strukturom kryminalnym.

Nawiązując do wypowiedzi Sołżenicyna, Andriej Siniawski pod pseudonimem Abram Terc, wziętym właśnie z folkloru przestępczego, opublikował w czasopiśmie Sintaksis szkic „Отечество. Блатная песня” (1979). Prócz ciekawych stwierdzeń na temat cech szczególnych twórczości przestępczej, do których jeszcze wypadnie tu wrócić, Terc ukazał, że teksty piosenek przestępczych doskonale wyrażają mentalność rosyjską i trudno je oddzielić od ogólnego strumienia twórczości narodowej.

Блатная песня. Национальная, на вздыбленной российской равнине ставшая блатной. То есть потерявшей, кажется, все координаты: чести, совести, семьи, религии... Но глубже других современных песен помнит она о себе, что - русская. [...] Когда от общества нечего ждать, остается песня, на которую все еще надеешься. И кто-то еще поет, выражая «душу народа» на воровском жаргоне, словно спрашивает, угрожая: русский ты или не русский?! (Терц 73)

Dla Siniawskiego, wytrawnego filologa, nienormatywna leksyka i obsceniczna, tabuizowana treść nie stanowią przeszkody w uznaniu pewnej wartości owej twórczości. Zwykle odrzucana i traktowana pogardliwie, z racji swojego niechlubnego pochodzenia i nieliterackiego języka, piosenka prze- 
stępcza wyróżnia się niespotykaną gdzie indziej szczerością i harmonijnością planów treści i formy.

Co warte podkreślenia, Siniawski, który swoje badanie oparł przede wszystkim na materiale zebranym w łagrach, nie wprowadza rozróżnienia na przestępców i niewinnych, skazanych i przebywających na wolności. Według niego piosenka przestępcza jest zjawiskiem o szerokim zasięgu, wpisującym się w ramy folkloru łagrowego.

Badacze zainteresowali się twórczością łagrową w latach 80., ale jej eksploracje mogły być oficjalnie rozwijane dopiero po upadku Związku Radzieckiego (Ефимова). Dzięki uwolnieniu od obciążeń sowieckiego reżymu stało się możliwe wydanie zbiorów folkloru obozowego oraz przeprowadzenie konferencji poświęconych temu zjawisku. Wtedy także zaznacza się nowe podejście do tego typu twórczości, gdyż nie mówi się o folklorze przestępców, lecz represjonowanych. Działalność literacka więźniów i zesłańców jest traktowana jako nieoficjalny i pozbawiony szans na przebicie się do kultury wysokiej wyraz sprzeciwu, jakby głos z otchłani: „он выступает как культура, противостоявшая античеловеческой системе, служившая выживанию, сохранению человека" (Путилов).

Folklor łagrowy traci więc wyjściowy jednoznaczny związek z subkulturą kryminalistów i oznacza bardzo szeroki zakres twórczości, ze szczególnym uwzględnieniem skrzywdzonych ofiar reżymu. W badaniach większy nacisk kładzie się na poetyzację doświadczeń osadzonych, heroizm ich postaw i cierpienie z powodu niesprawiedliwości. Ten typ folkloru jest więc raczej traktowany jako efekt przestępczego reżymu, a nie jako część twórczości przestępców. To raczej twórczość niewoli, która powstawała wbrew ograniczeniom i w zasadzie była przejawem wewnętrznej wolności. Boris Putiłow proponuje do zakresu owego terminu włączyć również: „фольклор тюрем, ссылок, поселений, спецприемников и детских домов, и вообще всех многочисленных мест несвободы, созданных тоталитарным режимом ради осуществления своих репрессивных целей” (Путилов).

$\mathrm{W}$ ten sposób pierwsza wspomniana przesłanka dla przyporządkowania poematu Dróżka do wyżej omówionej kategorii twórczości zyskuje potwierdzenie. Trzeba jednak pamiętać, że nie jest ona wystarczająca, bo przyporządkowanie nie powinno być automatyczne i nie powinno lekceważyć innych cech utworu, a także intencji autora, który folklorem łagrowym wcześniej określał inne zjawisko, nawet jeśli, jak już to zostało pokazane, ta sama nazwa ma teraz zupełnie inne znaczenie. 
Dodatkowe powody, dla których Sołżenicyn neguje wartość twórczości przestępczej i, pośrednio, dla których późniejsi literaturoznawcy nie lokują Dróżki w owej sferze, ujawniają przywołane tu już badania Siniawskiego:

Бывшие политзаключенные сталинской поры (58-я статья), на собственном горьком опыте узнавшие цену блатным, всю эту воровскую поэтику подчас и на дух не выносят. Слишком живо она облекается в плоть и кровь. (Терц 103)

Sołżenicyn należy właśnie do tych byłych łagierników, dla których różnica między twórczością kryminalistów i osadzonych inteligentów miała zasadnicze znaczenie. W obecnych badaniach pokazuję jednak, że obydwa te typy działalności twórczej rozwijały się paralelnie i wyodrębnienie ich elementów w strukturze jednego utworu jest niezwykle trudne. Dlatego, kiedy jest to możliwe bez nadużycia, stosuję te określenia zamiennie, pamiętając, że nie cała twórczość przestępcza może być zakwalifikowana do folkloru obozowego.

Tym, co zbliża badany poemat do folkloru łagrowego, jest więc na przykład dominanta tematyczna, czyli opowieść o życiu indywidualnego bohatera, która może być uogólniona. Młody człowiek przechodzi granicę między szczęśliwym życiem na wolności i egzystencją w niewoli. Dróżka ma charakter autobiograficzny i składa się $\mathrm{z}$ jedenastu rozdziałów, poświęconych różnym okresom życia bohatera. Nazwiska postaci występujących w utworze są jednak zaszyfrowane, a podmiot, zawsze wyrażony w pierwszej osobie liczby pojedynczej, określa się jako Sergiej Nierżyn. Okres na wolności zostaje, jak to bywa w poezji przestępczej, wyidealizowany, wypełniony udanymi decyzjami czy korzystnymi zbiegami okoliczności i to właśnie jemu poświęcone są niemal wszystkie rozdziały poematu. Liczba części składowych nie osiąga tradycyjnie i kulturowo oznaczającej pełnię wartości 12 i wskazuje na pewną otwartość utworu, który zresztą nie ma epilogu. Nierżyn, niemal jak bajkowy Iwanuszka, nieświadomy zła, które czyha na ludzi, rozpoczyna wędrówkę, nie dostrzegając, że każda droga, obiecująca początkowo szczęście i powodzenie, prowadzi go do przeznaczenia. Opowieść zostaje przerwana $\mathrm{w}$ momencie, gdy bohater staje $\mathrm{w}$ drzwiach więzienia na Łubiance $\mathrm{i}$ śmiało wchodzi $\mathrm{w}$ inny, przerażający świat. Poemat rozpoczyna się dwiema częściami wprowadzającymi, niewłączonymi do ogólnej numeracji, a są to Зарождение і Вступление. To właśnie te elementy poematu odsłaniają realia obozowe, które wskazują perspektywę, z jakiej przedstawione są losy bohatera. 
Чернеют вышки очерком знаковым.

От вышки к вышке день сочится над державою. (Солженицын, Дороженька 9)

Podobne obrazy sprawiają, że we wszystkich następnych rozdziałach szczególnego znaczenia nabierają fragmenty, w których bohater styka się ze śladami życia łagrowego, chociaż stara się ich nie dostrzegać i nie przyjmować do wiadomości, że w tym jakby innym, paralelnym świecie gułagowym prócz przestępców walczą o przetrwanie także niewinni ludzie. W rozdziale Серебрянные орехи bohater przybliża na przykład okoliczności aresztowania jego ukochanego dziadka oraz starszych przyjaciół. W rozdziale zaś Мальчики с Луны pełni młodzieńczego entuzjazmu studenci podczas wycieczki po Wołdze spotykają najpierw byłego więźnia, który - skazany za kułactwo - stracił w łagrach jedynego syna, potem niechcący trafiają w sam środek obławy na zeka, który uciekł z obozu w pobliżu Samary, a wreszcie mijają statek wiozący więźniów.

Эти лица! лица, обернувшиеся к солнцу!

И с бортов - конвойные штыки.

Вот они, кто там кирками машут! -

Только нескольких и рассмотрели мы.

Кто они?.. За что их?.. Не расскажут...(25)

Końcowy rozdział, poświęcony przeżyciom i rozmyślaniom konwojowanego aresztanta, nie zamyka historii, a jedynie doprowadza do przełomowego momentu, jakby zapowiedzianego już w częściach wstępnych. W tej chwili wszystkie rozwiązania są możliwe i to swoiste niedomknięcie fabularne harmonizuje $\mathrm{z}$ tytułem utworu, gdyż droga życiowa głównego bohatera ciągle trwa. Punkt w czasie i przestrzeni, w którym zostaje zapoczątkowana fabuła, oznacza więc moment i miejsce, z którego opowieść cofa się, aby dojść do swego początku i, bez zatrzymywania, toczyć się dalej. Bohater odwołuje się do figury okręgu, w który wpisuje się codzienność aresztanta:

Свой круг начну и я. И поведу - стихами:

Созвучной, мерной, может быть, сумею уберечь

Такой ценой открывшуюся речь! (10)

Motyw drogi, dający tytuł całemu poematowi, skorelowany z obrazem zamkniętego kręgu codzienności aresztanckiej, jest według Efimowej charakterystycznym elementem twórczości osadzonych: „для тюремной карти- 
ны мира характерно восприятие пространства как замкнутого, времени - как цикличного. Здесь две доминанты: путь и круг” (Ефимова).

Z autobiograficznością utworu związana jest obecność stałych elementów twórczości więziennej, a mianowicie motywów kobiety, domu, dawnego powodzenia czy Rosji (Терц 75-76):

Какая ты к чёрту родина,

Какая ты мать, позор?..

Позор мой, моё отечество!

В лохмотьях, завистно, грубо,

Во власти прохожей нечисти -

За что ты мне так любо?

Страна, где орлами-солдатами

За метр платят по сто,

Безсмысленную, проклятую,

Люблю я тебя за что? (Солженицын, Дороженька 200)

W folklorze łagrowym ojczyzna występuje zazwyczaj jako „wielka zona”, kraj upadły, który porównywalny jest ze wspólną celą, lub też matka, która cierpi z powodu niewoli swoich dzieci. Takie metafory pojawiają się nie tylko w liryce, ale w całej sferze kultury więziennej, na przykład w powiedzeniach czy tatuażach. Sołżenicyn nawiązuje do obrazu Rosji jako wielkiego więzienia, nieszczęsnego kraju, który nie zapewnia ludziom sprawiedliwości i bezpieczeństwa.

Калитку в чёрную пропасть

Пред мной отворяет страж.

Лубянка! Взяла ты полмира!

Ещё одного - прими!.. (206)

Ostatni cytat skłania do wyjścia w badaniach poza sferę motywów ku zagadnieniom problematyki i motywacji. Poemat w sumie wyraża kolektywne doświadczenie (Sulima 17), nie tylko współosadzonych bohatera i nie tylko pewnego pokolenia, lecz zapewne większości mieszkańców Rosji, którzy żyją w nieustannym zagrożeniu utraty wolności. Najdobitniej ten wyróżnik daje o sobie znać w jednym z wierszy wtopionych w strukturę Dróżki pod odrębnym tytułem Моему поколению.

Родились мы - не для счастья

Бредит, буен мир больной. 


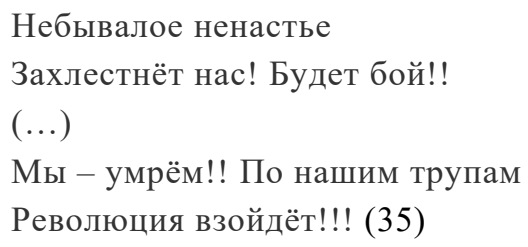

Nie jest to tylko pełne rozgoryczenia wspomnienie swojego zaślepienia, naiwności i bezgranicznego oddania sprawie rewolucji (Nikolson 261). Wydaje się, że pozycja bohatera lirycznego jest bardziej złożona, gdyż z perspektywy więźnia obozu przedstawia on własną historię jako swego rodzaju okrutne zobowiązanie, które uległo poetyzacji i było odbierane przez młodych ludzi jako piękny los bojownika o lepszą przyszłość. Indywidualne doświadczenia bohatera zyskują walor uogólnienia i stapiają się z doświadczeniami innych, którzy - tak jak on - padli ofiarą ideologii.

Kolejne przesłanki potraktowania poematu Dróżka jako przykładu folkloru łagrowego leżą poza strukturą utworu, lecz - jak wykażę - przekładają się na jego budowę. Jedną $z$ nich stanowi sposób utrwalenia i przekazu dzieła pierwszym odbiorcom. Jako zek Sołżenicyn notował bowiem najważniejsze obserwacje i przeżycia w postaci wierszowanej, następnie zapamiętywał je, niszcząc oryginały, żeby wreszcie - za pomocą specjalnego różańca - codziennie odtwarzać je z pamięci (Сараскина 365). Ta okoliczność pozwala przywołać bardzo ważny aspekt twórczości folklorystycznej, jakim jest oralność. Kategoria ta stanowi przedmiot pogłębionych badań folklorystów, reprezentujących różne opcje metodologiczne, którzy - za filozofami języka zwykle podkreślają prymarny charakter twórczości ustnej. Nie chodzi tu o wytwory kultury prymitywnej, powstającej w społecznościach nieznających pisma, lecz o uwydatnienie pierwotnej oralności języka (Ong 27), która ma szerokie implikacje filozoficzne. Słowo ma bowiem przewagę nad tekstem, ma moc sprawczą i pozostaje w szczególnym związku z sacrum (Goody 75). Dla obecnych rozważań ciekawe jest takie rozumienie ustności, które akcentuje interpersonalność, zdarzeniowość i wielowariantowość folkloru.

$\mathrm{Z}$ oralnością związany jest fakt, że utwory folklorystyczne funkcjonują w różnych wersjach (Пропп 24), bo odbiorca utworu mówionego może stać się jednocześnie nadawcą i dzieło folklorystyczne przekazywane jest w bezpośrednim kontakcie, a w każdym wykonaniu zyskuje nowy wyraz (Zumthor 127). U Sołżenicyna ta kategoria ma znaczenie nieco inne - przede wszystkim to pierwotny sposób tworzenia i bezpiecznego przechowywania tekstu literackiego. Utwór, który istniał przez długie lata jedynie w pamięci, nie 
mógł być wykorzystany jako dowód przeciwko autorowi, natomiast dzięki codziennemu odtwarzaniu go za pomocą chlebowego różańca twórca dbał o jego niezmienność. Odmawianie na różańcu, pierwotnie traktowane jako zabieg mnemotechniczny, z punktu widzenia obecnych badań staje się ważną cechą utworu. Wiadomo, że Sołżenicyn przedstawiał go współwięźniom na różnych etapach tworzenia, a więc faktycznie Dróżka dotarła do pierwszych odbiorców w różnych wersjach i mogła być przez nich dalej wykorzystywana oraz inspirować kolejne dzieła łagrowe. Według wspomnień Dmitrija Panina, który przebywał razem z Sołżenicynem w szaraszce Marfino, a potem w obozie w Ekibastuzie, autor, poczynając od 1951 r., recytował współwięźniom fragmenty poematu wierszem, który podówczas nazywał się Дорога i spotykał się z entuzjastycznym przyjęciem słuchaczy (Панин 479-480).

Kolejna przesłanka dla omawianej tu tezy także wiąże się z okolicznościami powstania utworu. Jest nią przemiana światopoglądowa, jakiej przyszły noblista doświadczył w więzieniu. Po tym swego rodzaju ideologicznym nawróceniu twórca musiał $\mathrm{w}$ jakiś sposób odciąć się od doktryny socrealistycznej, realizującej w formie literackiej zasady, które on właśnie zanegował. Przypomnę, że Sołżenicyn wiele lat wcześniej powziął kroki, aby zostać literatem, myśląc o pisarstwie jako o pewnym rodzaju pracy socjalistycznej, społecznie istotnej i związanej z określonymi wyszkolonymi umiejętnościami. Do samego aresztowania koncentrował się na zbieraniu materiałów i przygotowaniu szkiców do planowanych utworów (Сараскина 237-238). Ро odkryciu komunistycznego fałszu wyobrażenia młodego literata o twórczości musiały również ulec modyfikacjom.

Wraz z przemianą światopoglądową nastąpiło szczególne odkrycie znaczenia prawdy, która stała się swoistym hasłem przewodnim przyszłego pisarza. Można uznać, że dlatego w twórczości zaczął on poszukiwać takich środków wyrazu, które najtrafniej odwzorowywały otaczający świat. A ów świat cechowała ambiwalencja - głębokie życie duchowe, szlachetność przeciwników reżymu sowieckiego i niewinność ofiar nieludzkiej polityki spotykały się tu z bezwzględnością więziennych reguł, kryminalną hierarchią osadzonych, bezdusznością oraz prymitywizmem egzystencji. Ten dualizm, w moim pojęciu, odzwierciedla zmienność metryczna, niedokładność rymów i prostota brzmieniowo-rytmiczna utworu przy jednoczesnym zróżnicowaniu leksykalnych, syntaktycznych i semantycznych środków stylistycznych. Dobór tych ostatnich oddaje doświadczenie więzienne Sołżenicyna: z jednej strony, kontakt z przedstawicielami najświatlejszej niezależnej inteligencji radzieckiej i rozmowy pełne naukowych czy kulturowych nawiązań i refleksji, które 
później zostały utrwalone w powieści Krąg pierwszy (B круге первом, 1968), a z drugiej strony, żywioł przestępczy, wulgarny język, ordynarne zachowanie, niewyszukane piosenki i wiersze, które stanowiły przeciwwagę dla własnych zainteresowań autora.

Sołżenicyn, służąc zasadzie prawdy doświadczenia i odrzucając fasadowość oraz sztuczność językową twórczości socrealistycznej, wykorzystuje elementy folkloru więziennego, łącząc je z tym, co podówczas także jemu było bliskie $-\mathrm{z}$ językiem uwięzionych inteligentów i obrazowością kultury wysokiej. Powstały w ten sposób synkretyczny twór jest dość często spotykany w twórczości więźniów. Efimowa konstatuje, że łączenie słownictwa różnych rejestrów, a w szczególności włączanie do opowieści elementów, które świadczyć mogą o erudycji autora, jest typowe w różnych gatunkach folkloru łagrowego (Ефимова). Мa to swoje źródło w specyficznej dążności osadzonych do mistyfikacji i pozoranctwa.

Terc, pisząc o pieśni przestępczej, rozpoznaje tę cechę jako swego rodzaju teatralność, pojmowanie życia jako gry i skłonność do odgrywania w niej wielu ról (Терц 78). Szczególnie wyraźnie przejawia się to w ostatnim rozdziale Dróżki, kiedy aresztowany bohater jedzie pod konwojem do Moskwy i przekazuje ważną wiadomość dla żony, udając, że flirtuje z przygodnie poznanymi dziewczętami. Ten fragment wpisuje się w pełni w opowieści o zuchwałych wyczynach przestępców, którym umiejętnie udaje się wykorzystać najbardziej niesamowite okoliczności.

Sołżenicyn wykorzystuje obficie sentencje łacińskie, odniesienia do klasycznych utworów literackich czy Biblii, nie stroniąc od cytatów z życia więziennego, a nawet przekleństw. Wszystkie te zabiegi były zapewne zupełnie naturalne przy odbiorze ze słuchu, kiedy jednak Dróżka przyjęła formę pisaną, czytane poza kontekstem więziennym, okazały się niezrozumiałe. W posłowiu Sołżenicyn mówi o niedoskonałości technicznej swoich wierszy i szczególnie akcentuje te elementy, które odnoszą się właśnie do folkloru. Zwracając się bezpośrednio do swego dzieła, pisarz mówi: „я проклинал твой ритм, когда он был единственным ритмом моего дыхания” (208).

Autorowi przeszkadza rytmiczność, która, jak wiadomo z jego wspomnień, umożliwiała wykonywanie pewnych rozdziałów w formie śpiewanej. Dróżka w czasach jej tworzenia zawierała wiele powtórzeń i w okresie zesłańczym Sołżenicyn dobrał do wierszy nawet podkład muzyczny. Obecny jednak kształt utworu nie odzwierciedla w pełni oryginału obmyślanego w niewoli, a najstarszy jego maszynopis pochodzi już z okresu zesłania i wiadomo, że został przeredagowany. Śpiewność jednak niektórych frag- 
mentów poematu, osiągnięta kosztem precyzji wyrażeń i trafności metafor, jest do dzisiaj zauważalna.

\footnotetext{
Изгнившая вышка - призрак

С провалами чёрных дыр -

Да! Призраком Коммунизма

По Марксу вошла ты в мир.

Видением коммунизма

По Марксу вошла ты в мир. (205)
}

Niedoskonałość techniczna, przejawiająca się w niefortunności wyborów artystycznych, dysproporcji konstrukcji, nieumiejętnej selekcji materiału i nieporadności rymów, decydują o tym, że utwór Sołżenicyna zbliża się także do tzw. literatury naiwnej. Pojęcia „literatura naiwna”, a często także „twórczość naiwna” czy „naiwne pisarstwo” („наивная словесность”, „наивное письмо”, „наивное творчество”, „наивный дискурс”) funkcjonują już od dłuższego czasu w pracach rosyjskich folklorystów. Jest to określenie związane z zastosowanym tu dość szerokim rozumieniem folkloru, które na gruncie polskim, mimo braku odpowiedniego terminu, najłatwiej objaśnić na podstawie paraleli do sztuki naiwnej. Taka jest zresztą także proweniencja określenia rosyjskiego, chociaż z biegiem czasu badacze dostrzegają coraz wyraźniejsze różnice między tymi dwoma zjawiskami. W pracach wydawanych od lat dziewięćdziesiątych wybrzmiewa potrzeba dokładniejszego zdefiniowania twórczości naiwnej i opinia, że kwalifikacja do tej kategorii jest zwykle intuicyjna i subiektywna, a każdy artefakt jest rozpatrywany indywidualnie (Лурье 16).

Warto przywołać roboczą definicję, sformułowaną przez uczestników okrągłego stołu na temat „Что такое «наивная литература»?”, zorganizowanego w 2000 r. w Moskwie:

\footnotetext{
„Наивная литература” - это художественные (не прагматические) тексты, автор которых осознает себя как Автор (в отличие от фольклора); тексты, в которых неосознанно нарушаются нормы существующей литературной системы. Причем, для того, чтобы отнести произведение к “наивной литературе" нам необходимо рассматривать автора, как человека не имеющего ничего общего с литературой (в том числе и по социальному своему статусу). (Неклюдов, „От составителя” 11)
}

Pisarstwo naiwne jest więc domeną amatorów, którzy wykorzystują wzorce znanych utworów literackich, choć nie są świadomi reguł warsztatowych. 
Jest to twórczość łamiąca standardy poetyckie, zawierająca techniczne błędy i niekonsekwencje, ale zwykle pełna ekspresji i dotykająca spraw najważniejszych dla reprezentantów grupy społecznej, w której ramach powstaje. $\mathrm{Na}$ etapie odbioru jest trudno odróżnialna od stylizacji na prymitywizm, lecz czasem reprezentuje także zaskakująco wysoki poziom artystyczny. Znany folklorysta rosyjski Sergiej Niekludow twierdzi, że:

Это - продукция, как правило, рукописная и кроме того - «спонтанная», официально не санкционированная, производимая «на потребление», а не «на сбыт», т.е. непрофессиональная. (Неклюдов, „От составителя” 5)

Według badacza pojęcie literatury naiwnej najwygodniej konstruować na podstawie cech różniących ją od innych typów folkloru:

[...] ее тексты ориентируются на литературные (а не на устные) образцы; самими создателями они расцениваются как продукт индивидуального творчества (а не коллектива), включая выраженное авторское начало (в противоположность анонимному голосу фольклорной традиции). (Неклюдов, „Фольклорные”)

Literatura naiwna jest zatem traktowana zarazem jako część sfery folkloru oraz jako grupa zjawisk rozwijających się w opozycji do założeń twórczości folklorystycznej. Ów dysonans tłumaczy się tym, że środowisko jej powstania pokrywa się ze środowiskiem powstawania folkloru, lecz „twórcy naiwni”, zachowując folklorystyczny zestaw wartości i tematów, wyraźnie eksponują własną indywidualność oraz przedstawiają opinie. Badacze porównują więc czasem twórczość naiwną do „form parafolklorystycznych”. Dla naszych rozważań bardzo ważne jest stwierdzenie, że desygnatami omawianego terminu są teksty piosenek tworzonych w ramach różnych subkultur, a w szczególności liryka więzienna (Неклюдов, „От составителя” 5). Najbardziej istotnymi cechami tego pisarstwa są poczucie szczególnej misji i potrzeba wyrażenia pewnego kolektywnego doświadczenia (Неклюдов, „От составителя” 12).

Podobny cel przyświecał Sołżenicynowi, który w przedmowie i posłowiu do utworu wspomina kilkukrotnie, że pisanie wierszy było dla niego ratunkiem przed śmiercią: „Они были моим дыханием и жизнью тогда. Позволили мне выстоять" (5), a w wierszu pt. Над “Дороженькой», powstałym w 1953 r., poeta nazywa swoje dzieło: „Дочь моя! Душа моя!” (241). 
Zbawienne działanie twórczości nastawione było nie tylko na utrzymanie przy życiu, ale także na przekazanie wiedzy o pobycie na „nieludzkiej ziemi” innym ludziom. Twórca postawił przed sobą to samo zadanie, które później pojawia się w Achmatowowowskim Requiem, również umieszczając odpowiednią informację we wstępie do utworu. Sołżenicyn, tworząc w pełni amatorskie wiersze, jak twórcy literatury naiwnej, dąży do urzeczywistnienia najwyższego powołania literatury, powołania do głoszenia prawdy i prowadzenia ludzi. Autor Dróżki ma przed oczami wzorzec wieszcza narodu, który posiada dar proroczego słowa. Liczne niedomagania techniczne, którymi charakteryzuje się twórczość naiwna, nie oznaczają wcale porażki artystycznej. Badacze zgodnie twierdzą bowiem, że niewątpliwą siłą owej literatury jest autentyczność.

Bohater poematu akcentuje swoją osobowość i unikatowość, jednocześnie eksponując ogólne tło wydarzeń, które stanowi faktyczną motywację do podjęcia działań twórczych. Mimo że jego poezja odwołuje się do klasyki literatury i kultury wysokiej, to ma przede wszystkim znaczenie „użytkowe”, spychając na drugie miejsce wartości estetyczne. Sołżenicyn chce bowiem nade wszystko zachować pamięć o Gułagu, której ważnym elementem jest żywość obrazu i subiektywizm opisu.

$\mathrm{Na}$ podstawie przedstawionych rozważań można wysunąć wniosek, że liryka więzienna, powstająca pod wyraźnym wpływem otaczającego autora żywiołu folkloru łagrowego i faktycznie spełniająca warunki amatorskiej twórczości naiwnej, jest istotnym etapem w kształtowaniu się specyficznej metody autorskiej Sołżenicyna, której najważniejszymi cechami, według Andrzeja Drawicza, były funkcjonalność, ekspresywność, synkretyzm i subiektywizm (Drawicz 124-126). Odważne łączenie dyskursów, punktów widzenia, ironia i niezwykła dynamika wypowiedzi, które w perspektywie umożliwiły autorowi stworzenie utworów o potężnej sile wyrazu, bierze swój początek właśnie w niedoskonałym technicznie poemacie, który nosi na sobie ślady związku z otaczającą twórczością. Można zadać pytanie, dlaczego omawiany tu kontekst nie jest przywoływany przez środowisko badaczy spuścizny Sołżenicyna. Sądzę, że przyczyną tej sytuacji jest autorytet, jakim cieszył się pisarz w latach późniejszych oraz swoisty mit heroiczny, jaki nieustannie narastał wokół jego osoby. Wraz z więziennym strojem i skrawkami płótna $\mathrm{z}$ wymalowanym numerem, chlebowy różaniec do utrwalania w pamięci wersetów Dróżki stanowi jeden najcenniejszych eksponatów w osobistych zbiorach pisarza. W moim przekonaniu dzisiejsza pamięć o niezłomności pociąga za sobą wielkie oczekiwania czytelników i krytyków wzglę- 
dem utworu, który powstawał na długo wcześniej, w warunkach obozowych. Ta niewspółmierność oczekiwań ex post i celów, które stawiał sobie pisarz w łagrach, sprawiły, że jego poezja jest rozpatrywana poza ciekawym i istotnym kontekstem twórczości więziennej.

\section{BIBLIOGRAFIA}

Burszta, Józef. „Folklor”. Stownik etnologiczny. Terminy ogólne, red. Zofia Staszczak, PWN, 1987, ss. $124-127$.

Drawicz, Andrzej. „Spełniona misja sprzeciwu. Archipelag GUŁag Aleksandra Sołżenicyna”. Emigracja i tamizdat. Szkice o wspótczesnej prozie rosyjskiej, red. Lucjan Suchanek, Universitas, 1993, ss. 117-134.

Goody, Jack. Mit, rytuat i oralność. Przeł. Olga Kaczmarek, Wydawnictwa Uniwersytetu Warszawskiego, 2012.

Kowalski, Piotr. Wspótczesny folklor i folklorystyka. O przedmiocie poznania $w$ dzisiejszych badaniach folklorystycznych. Polskie Towarzystwo Ludoznawcze, 1990.

Ong, Walter J. Oralność i piśmienność. Stowo poddane technologii. Przeł. Józef Japola, Redakcja Wydawnictw Katolickiego Uniwersytetu Lubelskiego, 1992.

Sobczyk, Urszula. „Dzieje pojęcia „folklor” w polskim dyskursie humanistycznym”. Ogrody Nauk i Sztuk, nr 4, 2014, ss. 417-425.

Sulima, Roch. Folkor i literatura. Szkice o kulturze i literaturze wspótczesnej. Ludowa Spółdzielnia Wydawnicza, 1985.

Waliński, Michał, „Folklor i folklorystyka. Uwagi na marginesie definicji”. Literatura Ludowa, nr 4, 1977, ss. 3-26.

Wróblewska, Violetta. „Folklor - tradycja i współczesność. Wprowadzenie”. Folklor - tradycja i wspótczesność, red. Roksana Sitniewska, Elwira Wilczyńska, Violetta Wróblewska, Wydawnictwo Naukowe UMK, 2016, ss. 7-18.

Zumthor, Paul. „Właściwości tekstu oralnego”. Literatura ustna. Przeł. Maciej Abramowicz, red. Przemysław Czapliński, słowo/obraz terytoria, 2010, ss. 125-148.

Васюточкин, Георгий. „Дороженька Александра Солженицына”. На перевале тысячелетий: Страницы публицистики. Издатедьство Александра Сазанова, 2011, с. 356-363 [Vasyutochkin, Georgiy. „Dorozhen'ka Aleksandra Solzhenitsyna”. Na perevale tysyacheletiy: Stranitsy publitsistiki. Izdatel'stvo Aleksandra Sazanova, 2011, ss. 356-363].

Егоров, Михаил. „Тюремная лирика А.И. Солженицына: стихотворение «Воспоминания о Бутырской тюрьме»”. Верхневолжский филологический вестник, № 3, 2019, ss. 48-54 [Yegorov, Mikhail. „Tyuremnaya lirika A.I. Solzhenitsyna: stikhotvoreniye «Vospominaniya o Butyrskoy tyur'me»”. Verkhnevolzhskiy filologicheskiy vestnik, № 3, 2019, ss. 48-54]. cyberleninka.ru/article/n/tyuremnaya-lirika-a-i-solzhenitsyna-stihotvorenie-vospominaniyao-butyrskoy-tyurme/viewer. Dostęp 18.11.2019.

Ефимова, Елизавета С. „Субкультура тюрьмы и криминальных кланов” [Yefimova, Yeliaveta S. „Subkul'tura tyur'my i kriminal'nykh klanov”], www.ruthenia.ru/folklore/ efimova5.htm. Dostęp 18.11.2019. 
Лурье, Михаил. „О феномене «наивного» сочинительства”. Наивная литература исследования и тексты, ред. Сергей Неклюдов, Московский общественный научный фонд, 2001, ss. 15-28 [Lur'ye, Mikhail. „O fenomene «naivnogo» sochinitel'stva”. Naivnaya literatura issledovaniya i teksty", red. Sergey Neklyudov, Moskovskiy obshchestvennyy nauchnyy fond, 2001, ss. 15-28].

Неклюдов, Сергей. „От составителя”. Наивная литература исследования и тексты, ред. Сергей Неклюдов, Московский общественный научный фонд, 2001, ss. 4-14 [Neklyudov, Sergey. „Ot sostavitelya”, Naivnaya literatura issledovaniya i teksty, red. Sergey Neklyudov, Moskovskiy obshchestvennyy nauchnyy fond, 2001, ss. 4-14].

„Фольклорные традиции современного города”. Современный городской фольклор, ред. Александр Белоусов, Российский государственный гуманитарный университет, 2003, ss. 5-24. [,Fol'klornyye traditsii sovremennogo goroda”. Sovremennyy gorodskoy fol'klor, edited by Aleksandr Belousov, Rossiyskiy gosudarstvennyy gumanitarnyy universitet, 2003, ss. 5-24. folk.spbu.ru/Reader/nekludov1.php?rubr=Reader-articles. Dostęp 18.11. 2019].

Николсон, Майкл. „Да где ж ты была, дороженька? Жанровые поиски Солженицына в 4050-е годы". Путь Солженицына в контексте большого времени: сб. памяти: 19182008, ред. Людмила Сараскина, Русский путь, 2009, ss. 256-264 [Nikolson, Mayk1. „Da gde zh ty byla, dorozhen'ka? Zhanrovyye poiski Solzhenitsyna v 40-50-ye gody”. Put' Solzhenitsyna v kontekste bol'shogo vremeni: sb. pamyati: 1918-2008, red. Lyudmila Saraskina, Rusckiy put', 2009, ss. 256-264].

Панин, Димитрий. Лубянка - Экибастуз: Лагерные записки. Предисл. Исса Панина, Обновление, 1990 [Panin, Dimitriy. Lubyanka - Ekibastuz: Lagernyye zapiski. Predisl. Issa Panina, Obnovleniye, 1990].

Пропп, Владимир. „Специфика фольклора”. Фольклор и действительность. Избранные статьи, ред. Борис Путилов, Наука, 1976 [Propp, Vladimir. „Spetsifika fol'klora”. Fol'klor i deystvitel'nost'. Izbrannyye stat'i, red. Boris Putilov, Nauka, 1976].

Путилов, Борис. „Фольклор ГУЛАГа как факт культуры”. [Putilov, Boris. „Fol'klor GULAGa kak fakt kul'tury"], ruthenia.ru/folktee/CYBERSTOL/GULAG/Putilov.html. Dostęp 18.11. 2019.

Пьералли, Клаудия. „Поэзия ГУЛАГА: теоретические и эпистемогогические основания”. Studia Litterarum, vol. 3, nr 2, 2018, cc. 144-163 [P'yeralli, Klaudiya. „Poeziya GULAGA: teoreticheskiye i epistemogogicheskiye osnovaniya”, vol. 3, nr 2, 2018, ss. 144-163].

Сараскина, Людмила. Александр Солженищын. Молодая гвардия, 2009 [Saraskina, Lyudmila. Aleksandr Solzhenitsyn. Molodaya gvardiya, 2009].

Солженицын, Александр. „Предисловие к публикации Два лагерных стихотворения”. Вестник русского христианского движения, nr 117, 1976, с. 148 [Solzhenitsyn, Aleksandr. „Predisloviye k Publikatsii Dva lagernykh stikhotvoreniya”. Vestnik russkogo khristianskogo dvizheniya, nr 117, 1976, s. 148].

- Архипелаг ГУЛаг. 1918-1956. Опыт художественного исследования, t. 2. Азбука, 2014 [Arkhipelag GULag. 1918-1956. Opyt khudozhestvennogo issledovaniya, t. 2. Azbuka, 2014]. . Дороженька. Вагриус, 2004 [Dorozhen 'ka. Vagrius, 2004].

Терц, Абрам. „Отечество. Блатная песня”. Синтаксис, № 4, 1979, ss. 72-118 [Terts, Abram. „Otechestvo. Blatnaya pesnya”. Sintaksis, № 4. 1979, ss. 72-118]. 


\section{DRÓŻKA ALEKSANDRA SOŁŻENICYNA \\ W KONTEKŚCIE LITERATURY NAIWNEJ I FOLKLORU ŁAGROWEGO}

\section{Streszczenie}

Tekst stanowi próbę przedstawienia wczesnych utworów poetyckich Aleksandra Sołżenicyna na tle twórczości folklorystycznej i parafolklorystycznej. Poemat Dróżka, który jest głównym obiektem eksploracji, zawiera materiał tematyczny wykorzystany później w najsłynniejszych dziełach prozatorskich Sołżenicyna. Autorka artykułu omawia powody, dla których folklor łagrowy i literatura naiwna powinny być uwzględnione w badaniach nad wczesną twórczością pisarza. Ich cechy, takie jak specyficzny zestaw motywów, oryginalne podejście do świata, oralność, autentyczność, wielowariantowość czy przekazywanie kolektywnego doświadczenia, pozwalają za techniczną niedoskonałością wierszy dostrzec ważny etap w formowaniu oryginalnego stylu twórcy.

Słowa kluczowe: folklor; folklor łagrowy; literatura naiwna; oralność.

\section{THE TRAIL BY ALEKSANDR SOLZHENITSYN \\ IN THE CONTEXT OF LABOUR CAMP FOLKLORE AND NAÏVE LITERATURE}

\section{S u m m a ry}

This paper is an attempt to present Aleksandr Solzhenitsyn's early poetry against the background of folkloric and parafolkloric works of art. The poem The Trail, which is the subject of this research, provided the material for the most famous of Solzhenitsyn's prose works. The author of this article shows the reasons why labour camp folklore and naïve literature should be taken into consideration in any interpretations of the writer's early works. Some of its features, such as the specific complexity of motifs, its original attitude towards the world, its oralness, verity, multiplicity of versions, as well as the provision of a collective experience despite its technical imperfection, make it possible to perceive it as an important stage in the process of creating Solzhenitsyn's original, individual style.

Key words: labour camp folklore; folklore; naïve literature; oralness. 